\title{
Earnings Management : Empirical Evidence on Determinants in Indonesia
}

\author{
Nurlis, Nurlis., Indriawati, Fitri. \\ Univesitas Mercu Buana, Jakarta, Indonesia \\ Ariani, Meiliyah., Prihanto, Hendi. \\ Universitas Prof. Dr. Moestopo (Beragama)
}

\begin{abstract}
Earnings management is a way to present earnings adjusted to the goals desired by managers and is done through the selection of accounting policies or through accrual management. This study aims to determine the effect of leverage, tax planning, size and good corporate governance mechanisms on earning management. The sample of this research is the manufacturing companies in the consumer goods industry sector which are listed on the Indonesia Stock Exchange in 2015 - 2017 totaling 23 companiesThe results of the study that Leverage, Tax Planning, Size and Audit Committee have a significant effect on Earning Management, while independent commissioners have no significant effect on earnings management

Keywords: Earning Management, Leverage, Tax Planning, Size, Good Corporate Governance mechanisms, Audit Committee, Independent Commissioner

DOI: $10.7176 / \mathrm{EJBM} / 12-3-04$
\end{abstract}

Publication date: January $31^{\text {st }} 2020$

\section{A. INTRODUCTION}

Quality financial statement will have a positive impact on users that it can avoid misleading information. If the information contained in the financial statements is manipulated, it will reduce the quality of the financial statements (Rahmawati, 2013). Some of the information contained in the financial statements will be used by interested parties in the company including the company's leadership, owners, creditors, investors, government, and employees. Information about company profits can be used as a measure of management performance, as a basis for compensation and bonus distribution, as well as indicators of the efficiency of the use of funds embedded in the company that is realized in the rate of return. Some investors who have an interest will focus their attention on the company's earnings information with its share of ownership without looking at other factors in the financial statements. Thus, this will be used as a reference by company managers in carrying out earnings management actions (Hery, 2016).

Earnings management can be mentioned as one of the practices of signaling (including real earnings management and accrual-based earnings management). Earnings management is the process of getting desirable earnings through manipulations, within the limitations of generally accepted accounting practice (Davidson, Stickney \& Weil, 1985). Similarly, Healy \& Wahlen (1999) defined earnings management as "intervention in the financial reporting process, with the intention to get some personal or private gain". Earnings management is possible due to the discretion available to managers in preparing financial reports (Kamarudin \& Ismail, 2014). Managers have the discretions to transfer current income to future periods or they can even defer expense through different accounting techniques without the violation of general accepted accounting principles (Dechow \& Schrand, 2004). In addition, managers involve in earnings management due to the need for external financing and avoid taxes (Bauwhede, 2001). Moreover, firms manage earnings to affect stock prices (Healy \& Wahlen, 1999). Similarly, prior to seasoned equity offerings (SEO), firms manage earnings to increase share prices (Dechow \& Schrand, 2004). Management is managing earnings to meet benchmark and target earnings (Burgstahler \& Dichev, 1997). On the other hand, some management involves in earnings management to improve the financial image of the firm; through meeting the expectation of investors and forecasted profit of the analyst (Degeorge, Patel \& Zeckhauser, 1999). Therefore, high earnings quality exists in the absence of earnings management, since unmanaged earnings are of higher quality when compared to managed earnings (Dechow \& Schrand, 2004).

The case that have occurred regarding earnings management practices is that PT Bank Bukopin Tbk revised its financial statements in the last three years, namely 2015, 2016, and 2017. Bank Bukopin revised its 2016 net profit which was previously $\mathrm{Rp} 1.08$ trillion to $\mathrm{Rp} 183.56$ billion. The biggest decrease was in the portion of fee and commission income which was income from credit cards. This income dropped from $\mathrm{Rp} 1.06$ trillion to $\mathrm{Rp}$ 317.88 billion. In addition to the credit card problem, a revision also occurred in the financing of a subsidiary of Bank Syariah Bukopin (BSB) related to the addition of an allowance for impairment losses for certain debtors. As a result, the allowance for impairment losses on financial assets was revised to increase from Rp 649.05 billion to Rp 797.65 billion. This caused the company's burden to increase by Rp 148.6 billion. In another case, the Financial Services Authority (OJK) managed to find irregularities committed by PT Sunprima Nusantara Financing (SNP 
Finance). OJK supervisors have seen unusual practices in SNP reports since July 2017. PT SNP's annual financial reports have been audited by public accountants from Public Accounting Firm Satrio, Bing, Eny and Partners and get unqualified opinion. However, based on the results of the OJK examination, PT SNP Finance has indicated that it has presented financial statements that are significantly not in accordance with the actual financial condition, thus causing many parties to suffer. Police Headquarters found allegations of burglary funds in 14 banks, both private and state-owned enterprises, conducted by SNP Finance. The amount according to Bareksrim's findings is around Rp. 14 trillion. Earnings management occurs because there are differences in interests between the parties involved (company owners, management, and government).

The purpose of this study is to determine the effect of leverage, tax planning, size and mechanism of good corporate governance on earnings management in the manufacturing companies in the consumer goods sector for the period 2015-2017. The decision to use manufacturing companies in the consumption sector is because they are more easily influenced by economic conditions and have a high level of sensitivity to any event both internal and external to the company.

\section{B. Framework of Thinking and Hypothesis}

According to Prihadi (2012: 263), leverage ratio is a ratio to measure a company's ability to pay off debt which can be compared to assets or own capital. The relationship between the interest arising from debt and the profits generated can be also viewed. The less the debt, the lower the financial risk will be (financial risk). High leverage becomes the driver of earnings management actions taken by management so that the company can avoid violating debt agreements (Partayadnya, 2018). Research conducted by Priharta (2018), Astuti (2017) and Mulyana (2018) concluded that leverage has an influence on earnings management.

Increased profits can affect high tax payments and cause companies to incur a greater burden so companies do tax planning to minimize the smallest possible tax payments while still getting high profits. The research conducted by Dewi (2017), Lubis (2018), and Fitriany (2016) concluded that tax planning affects earnings management.

The greater the total assets and sales, the greater the size of a company is. The greater the assets, the greater the capital is invested, while the more sales, the more the velocity of money in the company is (Hery, 2017: 12). Large companies are faced with high political costs, so large companies tend to use accounting principles that can reduce the value of earnings statements to reduce political magnitude. Supported by research conducted by Satya (2014), Lubis (2018) and Gustinya (2016), it is concluded that company size affects earnings management

The existence of audit committee in a company will directly affect the arrangement and accounting reporting of the company concerned (Savitri, 2016: 69). The audit committee meets in a year for the audit committee meeting. The more frequently the audit committee holds the frequency of the meetings, the more intense the discussion of the company activities and financial statements be held, so that it will have an impact on the declining of earnings management. Research conducted by Lufita (2018), Yendrawati (2015), and Partayadnya (2018) conclude that the audit committee affects earnings management.

The existence of this board will have an effect on the quality of financial statements and is used as a measure of the level of financial engineering carried out by a manager. Independent commissioners can affect the management in preparing financial statements so that quality reports are obtained and they can reduce the opportunity to do earnings management (Zeptian, 2013). The results of research conducted by Putra (2018), Nurlis (2016) and Zeptian (2013) conclude that independent commissioners affect earnings management.

Based on this explanation, the research hypothesis can be formulated as follows:

H1: Leverage affects earnings management.

$\mathrm{H} 2$ : Tax Planning has an effect on earnings management.

H3: Size affects earnings management.

H5: Independent Commissioner affects earnings management.

H4: Audit Committee affects earnings management.

The framework of thinking in this study is as follows: 


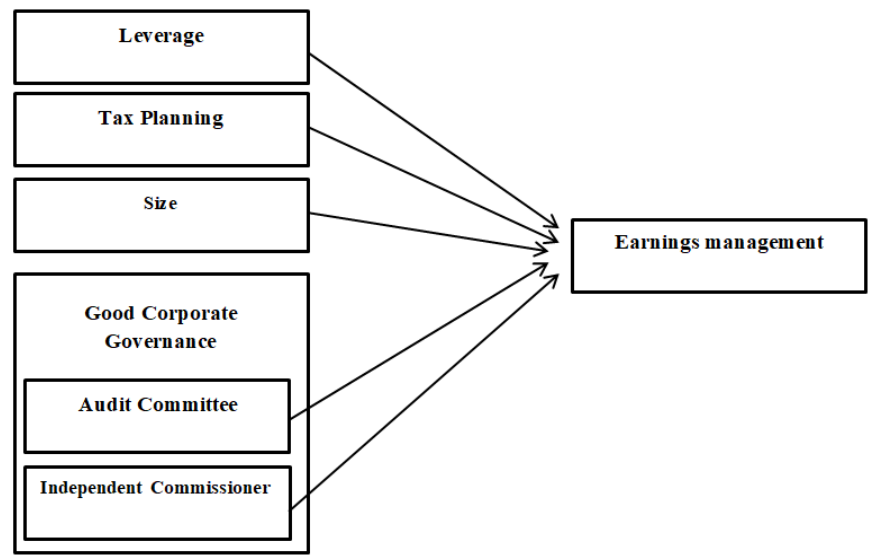

Figure 1 Conceptual Research Model

\section{Research Methodology}

The method used in this study is a causal method with a quantitative approach to empirically prove the relationship between independent variables namely leverage, tax planning, company size and the mechanism of good corporate governance on earnings management. To empirically prove the effect of the independent variables on the dependent variable, the variables in this study are measured by indicators as in table 1 below.

Table 1

Operationalization of Variables

\begin{tabular}{|c|l|l|c|}
\hline No & \multicolumn{1}{|c|}{ Variable } & Indicator & Scala \\
\hline 1 & Earning Management $(\mathrm{Y})$ & RDA $=\frac{T A C}{T A i t-1}$ & Ratio \\
\hline 2 & Leverage $\left(X_{1}\right)$ & $D A R=\frac{\text { Total } \text { Debt }}{\text { Total Asset }}$ & Ratio \\
\hline 3 & Tax Planning $\left(X_{2}\right)$ & $T R R=\frac{\text { Net income t }}{\text { Pre_tax income (EBIT) } t}$ & Ratio \\
\hline 4 & Firm Size $\left(\mathrm{X}_{3}\right)$ & Size $=$ Ln Total Asset & Ratio \\
\hline 5 & Audit Committee $\left(X_{4}\right)$ & $\sum$ Audit Committee Meetings & Ratio \\
\hline 6 & $\begin{array}{l}\text { Independent } \\
\text { Commissioners }\left(X_{5}\right)\end{array}$ & $\frac{\sum \text { Independent Commissioners }}{\sum \text { Commissioners }}$ & Ratio \\
\hline
\end{tabular}

The sample of this study is the annual financial statements of manufacturing companies listed on the Indonesia Stock Exchange, as many as 23 companies, in which the statement of each company is taken for 3 years from the 2015-2017 period, so that the total sample of data in this study is 69 data. The tool used to analyze this research is e-views version 9.0. This study uses panel data regression analysis method which is analyzed using the fixed effect cross-section weights model (FEM EGLS) to determine whether there is a significant effect between the independent variables namely leverage, tax planning, company size and the mechanism of good corporate governance on the dependent variable, earnings management.

\section{Data Analysis and Hypothesis Testing}

Based on the data normality test using a test developed by Jarque - Bera, the result is that JB values of 4.811407 are less than the results of the chi-square table and p-values which is more than 0.05 . It is concluded that this research data is normally distributed, likewise, the multicollinearity test can be seen from the collections between independent variables below 0.95. The Park test conducted to detect whether the research data is free from heteroscedasticity or not provides results that the probability value of each independent variable is above 0.05 , meaning that it is not affected by heteroscedasticity. Whereas, based on the autocorrelation test seen from the Durbin Watson, the value is 2.048182 , with $\mathrm{n}=69, \mathrm{k}=5$, the result obtained are $\mathrm{dl}=1.7680$ and $\mathrm{du}=1.4588$. The formula to determine whether the results of the study is autocorrelated or not is $\mathrm{du}<\mathrm{dw}<(4-\mathrm{du})$, the results of the study indicate that it is in the autocorrelation free position ie at the position of $\mathrm{dU}<\mathrm{d}<4-\mathrm{dU}$ or $1.4588<2.0481$ $<2.232$. The conclusion is that this research is in an autocorrelation free area. 
Table 2

\begin{tabular}{llll}
\multicolumn{4}{c}{ Weighted Statistics } \\
\hline \hline R-squared & 0.839364 & Mean dependent var & -0.028906 \\
Adjusted R-squared & 0.733579 & S.D. dependent var & 0.070918 \\
S.E. of regression & 0.035646 & Sum squared resid & 0.052095 \\
F-statistic & 7.934646 & Durbin-Watson stat & 2.048182 \\
Prob(F-statistic) & 0.000000 & & \\
\hline \hline
\end{tabular}

The $\mathrm{F}$ count is 7.9346 with a statistical probability level of $0.00<0.05$, which means the regression model can be used to predict earnings management. The adjusted R2 shows a value of 0.733 , it is said that the independent variable consisting of leverage, tax planning, company size and good corporate governance mechanism affects earnings management by $73.3 \%$, while $26.7 \%$ is influenced by other variables outside the model.

Table 3

Fixed Effect Model Cross-Section Weight

\begin{tabular}{lrrrr}
\hline \hline Variable & \multicolumn{1}{c}{ Coefficient } & \multicolumn{1}{l}{ Std. Error } & \multicolumn{1}{c}{ t-Statistic } & \multicolumn{1}{l}{ Prob. } \\
\hline \hline C & -2.164036 & 0.609889 & -3.548244 & 0.00100 \\
DAR & 0.155984 & 0.025024 & 6.233246 & 0.00000 \\
TP & 0.188997 & 0.090895 & 2.079296 & 0.04390 \\
SIZE & 0.069185 & 0.021157 & 3.270100 & 0.00220 \\
AC & -0.005209 & 0.001378 & -3.780798 & 0.00050 \\
IC & -0.095020 & 0.116359 & -0.816609 & 0.41890 \\
\hline \hline
\end{tabular}

Based on the $t$ test shown in table 3, the variable leverage, tax planning, company size, and audit committee have a significant effect on earnings management, while the independent commissioners have no effect on earnings management.

\section{E. Discussion and Research Results}

This research explores the effect of leverage, tax planning, company size, audit committee and independent commissioners on earnings management. Based on the research that has been done, the description of the results is as follows:

\section{The Effect of Leverage on Earning Management}

The results show that leverage (DAR) has a significant effect on earnings management (NDA), so H1 is accepted. This result is in line with the agency theory according to Jensen and Meckling (1976) that with the existence of a cost agency, management will be able to optimize earnings management from the influence of leverage. This means that if the company has a high debt to fund its assets or investments, the manager will conduct earnings management to manage the profit figures generated by having goals such as to attract investors or creditors who want to provide loan funds or contract extension.

These results are in line with research conducted by Priharta (2018), Astuti (2017) and Mulyana (2018) who conclude that leverage affects earnings management but it is not in accordance with the results of Betaubun's research (2015) who says that leverage has no effect on earnings management.

\section{The Effect of Tax Planning on Earning Management}

The results show that tax planning (TP) has a significant effect on earnings management so it is concluded that $\mathrm{H} 2$ is accepted. On the contrary, this result is not in line with the signaling theory according to Brighanm (2011), in tax planning, several companies take earnings management actions which causes the information occur is not in accordance with the actual situation. With the change in tax rates, the company management regulates the amount of reported profits. The higher the profits obtained by the company, the greater the possibility of the amount of tax borne by the company. One of the actions taken by company management to avoid such events is to manage reported earnings, so that these actions reflect indications of earnings management practices within the company.

The results are also consistent with research conducted by Dewi (2017), Lubis (2017) and Fitriany (2016) which state that tax planning has an influence on earnings management. However, the results of this study are not in accordance with research conducted by Mulyania (2018) stating that tax planning has no effect on earnings management.

\section{The Effect of Company Size on Earning Management}

The results show that company size (SIZE) has a significant effect on earnings management which is in line with the signaling theory according to Brighanm (2011). The size of the company becomes one of the considerations for investors to invest their shares or not in the company. Large companies are faced with high political costs, so companies are motivated to do earnings management by smoothing earnings to reduce political costs. This study is in line with the research conducted by Satya (2014), Lubis (2018) and Gustinya (2016) which states that company size influences earnings management, but it is not in line with Arifin (2016) research stating that company size has no effect on earnings management. 


\section{The Effect of Audit Committee on Earning Management}

The results of this study indicate that the audit committee has a significant influence on earnings management which is in line with agency theory according to Jensen and Meckling (1976) stating that company management must be monitored by an audit committee meeting. Audit committee meetings can make management issue accountability reports in line with the interests of the company's owners. The negative sign indicates an opposite relationship meaning that if the audit committee variable has increased by one unit, the value of earnings management will decrease by -0.005 and vice versa assuming the value of the other variables is constant. The audit committee has been able to carry out oversight responsibilities of the company's financial reporting process well so that the credibility of the audited financial statements is achieved and can reduce the existence of earnings management efforts by management.

This is in line with research by Lufita (2018), Yendrawati (2015) and Partayad (2018) stating that the audit committee influences earnings management, but not in line with research conducted by Amar (2014) which states that the audit committee has no effect on earnings management.

\section{The Effect of Independent Commissioners on Earning Management}

The results show that independent commissioners have no influence on earnings management. The triggering factors for agency problems are the information asymmetry. The role of the independent commissioner is to provide fair treatment to minority shareholders and other stakeholders and ensure the transparency and the disclosure of the company's financial statements. But, in this study, the independent commissioner has no effect on earnings management. The no effect result is caused by the role of independent commissioners which is to realize objectivity, independence, fairness, and can provide a balance between the interests of the majority shareholders and also the protection of minority shareholders, even to the interests of other stakeholders, so it is not directly involved by the company's operations and it is said that the formation of an independent commissioner is only limited to compliance with regulations so that it does not affect management activities.

The results of this study are in line with research conducted by Yendrawati (2015) stating that independent commissioners have no effect on earnings management. However, this study is not in line with research conducted by Putra (2018), Nurlis (2016) and Zeptian (2013) who conclude that independent commissioners affect earnings management.

\section{F. Conclusion}

Based on the hypothesis testing and discussion, it is concluded that leverage, tax planning, company size and audit committee have a significant effect on earnings management, while the independent commissioner does not significantly affect earnings management. The Determination Coefficient (Adjusted R2) in this study which is amounted to $73.3 \%$, then investors can judge whether the company take earnings management actions or not through leverage, tax planning, company size, audit committees and independent commissioners in the company.

I would like to express my great appreciation to the research center for financial support for my research

\section{REFERENCES}

Amar, Anis Ben. (2014). The Effect of Independence Audit Committee on Earnings Management: The Case in French. International Journal of Academic Research in Accounting, Finance and Management Sciences. Vol. 4, No.1.

Arifin, Lavenia dan Nicken Destriana. (2016). Pengaruh Firm Size, Corporate Governance dan Karakteristik Perusahaan Terhadap Manajemen Laba. Jurnal Bisnis dan Akuntansi. Vol. 18.

Astuti, Ayu Yuni, Elva Nuraina, Anggita Langgeng Wijaya. (2017). Pengaruh Ukuran Perusahaan dan Leverage Terhadap Manajemen Laba. Forum Ilmiah Pendidikan Akuntansi. Vol. 5, No. 1, 501-514.

Dewi, Eva Rafika, Elva Nuraina. (2017). Pengaruh Tax Planning Dan Ukuran Perusahaan Terhadap Manajemen Laba. Forum Ilmiah Pendidikan Akuntansi. Vol. 5, No. 1, 854-881.

Dechow, P. M., \& Schrand, C. M. (2004). Earnings quality

Fitriany, Lucy Citra. (2016). Pengaruh Aset Pajak Tangguhan, Beban Pajak Tangguhan Dan Perencanaan Pajak Terhadap Manajemen Lab. JOM Fekon. Vol. 3, No. 1.

Gustinya, Diana. (2016). Analisis Pengaruh Kepemilikan Institusional, Komisaris Independen, Dewan Direksi, Ukuran Perusahaan dan Leverage Terhadap Manajemen Laba Pada Perusahaan Non Keuangan Yang Terdaftar Di BEI Tahun 2011-2014. Jurnal Akuntansi Bisnis, Vo. 3, No. 1.

Healy, P. M., \& Wahlen, J. M. (1999). A review of the earnings management literature and its implications for standard setting. Accounting horizons, 13(4), 365-383.

Hery. (2016). Analisis Laporan Keuangan. Jakarta: PT Grasindo.

Hery. (2017). Kajian Riset Akuntansi. Jakarta: PT Grasindo.

Lubis, Irsan, Suryani. (2018). Pengaruh Tax Planning, Beban Pajak Tangguhan Dan Ukuran Perusahaan Terhadap Manajemen Laba. Jurnal Akuntansi dan Keuangan. Vol. 7, No. 1.

Lufita, Novi, Elly Suryani. (2018). Pengaruh Kualitas Audit, Komite Audit, Dan Ukuran Perusahaan Terhadap 
Manajemen. e-Proceeding of Management. Vol. 5, No. 1.

Mappanyukki, Ratna \& Haryo, D. Prakoso \& Soni, A.Irwandi, (2016). The Impact of Free Cash Flow and Good Corporate Governance (GCG) Earning Management of the Banking Companies Listed on the Indonesia Stock Exchange. Research Journal Finance and Accounting

Mulyana, Ayu, Zuraida, Mulia Saputra. (2018). The Influence of Liquidity, Profitability and Leverage on Profit Management and Its Impact on Company Value in Manufacturing Company Listed on Indonesia Stock Exchange Year 2011-2015. International Journal of Managerial Studies and Research (IJMSR). Vol. 6, PP 8-14.

Mulyania, Noviana, Kartika Hendra, Riana Rachmawati. (2018). The Effect of Tax Planning and Deferred Tax Expense on Earnings Management on Manufacturing Companies Listed In The Indonesia Stock Exchange. The 2nd International Conference on Technology, Education, and Social Science 2018.

Nurlis. (2016). The Effect of Mechanism of Good Corporate Governance and Investment Opportunity Set on the Earning Management: Study On Property and Real Estate Companies Are Listed In Indonesia Stock Exchange. European Journal of Business and Management. Vol. 8, No. 2.

Partayadnya, I Made Arya. (2018). Pengaruh Mekanisme GCG, Kualitas Audit, dan Leverage Terhadap Manajemen Laba pada Perusahaan Manufaktur di BEI. E-Jurnal Akuntansi Universitas Udayana. Vol. 25, No. 1, 31-53.

Prihadi, Toto. (2012). Praktis memahami laporan keuangan sesuai IFRS \& PSAK. Cetakan II. Jakarta Pusat: PPM.

Priharta, Andry, Dewi Puji Rahayu, dan Bambang Sutrisno. (2018). Pengaruh CGPI, Kualitas Audit, Ukuran Perusahaan dan Leverage Terhadap Manajemen Laba. Journal of Applied Business and Economics. Vol. 4, No. 4.

Putra, Dimas Adriansyah, Farida Titik Kristanti, Wiwin Aminah (2018). Pengaruh Mekanisme GCG, Kualitas Audit, dan Leverage Terhadap Manajemen Laba pada Perusahaan Manufaktur di BEI. e-Proceeding of Management. Vol. 5, No. 2.

Rahmawati, Hikmah Is'ada. (2013). Pengaruh Good Corporate Governance Terhadap Manajemen Laba Pada Perusahaan Perbankan. Accounting Analysis Journal.

Satya, Indra, I Gusti Ketut dan I Gusti Ayu. (2014). Analysis of firm size, leverage, corporate governance on earnings. Journal of Economics, Business, and Accountancy Ventura. Vol. 17.

Savitri, Enni. (2016). Konservatisme Akuntansi-Cara Pengukuran, Tinjauan Empiris dan Faktor-Faktor yang Mempengaruhinya. Yogyakarta: Pustaka Sahila.

Yendrawati, Reni. (2015). Pengaruh Dewan Komisaris Independen, Komite Audit, Kepemilikan Manajerial, dan Kepemilikan Institusional terhadap Manajemen Laba. Jurnal Entrepreneur dan Entrepreneurship. Vol. 4, No. 1-2.

Zeptian, Andra dan Abdul Rohman. (2013). Analisis Pengaruh Penerapan Corporate Governance, Struktur Kepemilikan, dan Ukuran Perusahaan Terhadap Manajemen Laba Pada Perbankan. Diponegoro Journal Of Accounting. Vol. 2, No. 4.

www.kompas.com 